\title{
Importance of climate, anthropogenic disturbance and pathogens (Quambalaria coyrecup and Phytophthora spp.) on marri (Corymbia calophylla) tree health in southwest Western Australia
}

\author{
Trudy Paap ${ }^{1,2}$ • Niels C. Brouwers ${ }^{1}$ • Treena I. Burgess ${ }^{1}$ - Giles E. St. J. Hardy ${ }^{1}$
}

Received: 25 February 2017 / Accepted: 18 July 2017 /Published online: 14 August 2017

(C) INRA and Springer-Verlag France SAS 2017

\begin{abstract}
- Key message Anthropogenic disturbance and Phytophthora spp., influenced by climate, are resulting in a higher Quambalaria coyrecup infection probability in marri (Corymbia calophylla) and the development of cankers, causing a decline in marri health across the geographical range in southwest Western Australia.

- Context Since the 1970s, a canker disease caused by the endemic fungal pathogen Quambalaria coyrecup Paap has
\end{abstract}

Handling Editor: Cécile Robin

Contribution of the co-authors

Trudy Paap was responsible for the experimental design, data collection in the field, soil sample analysis in the laboratory and writing of the manuscript.

Niels Brouwers was responsible for data analyses and writing of the manuscript.

Treena Burgess was responsible for supervising the work, coordinating the research project, contributing ideas and reviewing the manuscript. Giles Hardy was responsible for supervising the work, coordinating the research project, contributing ideas and reviewing the manuscript.

Niels C. Brouwers

n.brouwers@murdoch.edu.au

Trudy Paap

trudy.paap@ fabi.up.ac.za

Treena I. Burgess

t.burgess@murdoch.edu.au

Giles E. St. J. Hardy

g.hardy@murdoch.edu.au

1 Centre of Excellence for Climate Change, Woodland and Forest Health, Murdoch University, Murdoch 6150, Australia

2 Department of Microbiology and Plant Pathology, Forestry and Agricultural Biotechnology Institute (FABI), University of Pretoria, Pretoria, South Africa increasingly affected the health of marri (Corymbia calophylla (Lindl.) K.D. Hill \& L.A.S. Johnson), a keystone tree species in southwest Western Australia.

- Aims In this study, we investigated the distribution and incidence of the canker disease, and the likely predisposing location-specific factors of the disease across the marri range. - Methods A systematic landscape-scale survey was undertaken at 62,100-m radius sites, and canker incidence was related with climate, rainfall and temperature change, proportion nonnative vegetation area (i.e. anthropogenic disturbance) and Phytophthora spp. presence using logistic regression.

- Results On 54 sites, between 2 and $78 \%$ of all surveyed trees showed cankers. Eight sites were canker free. Since 1980, all sites experienced a reduction in annual rainfall (2.2$136.1 \mathrm{~mm})$ and increasing temperatures $\left(0.17-0.53{ }^{\circ} \mathrm{C}\right)$. Multivariate analyses showed that across the marri range, canker incidence was significantly higher in wetter and cooler areas of the marri distribution, and in areas with high proportions of non-native vegetation area surrounding the studied stands of trees. Presence of pathogenic Phytophthora spp. equally increased canker incidence.

- Conclusion Our study suggests that anthropogenic disturbance and Phytophthora presence may have reduced the natural defence mechanisms of marri trees, making them more vulnerable to the development of mortality inducing cankers.

Keywords Quambalaria coyrecup · Phytophthora · Fungal pathogen $\cdot$ Corymbia calophylla $\cdot$ Marri $\cdot$ Mediterranean-type ecosystem

\section{Introduction}

Global changes in atmospheric $\mathrm{CO}_{2}$ concentration and climate, combined with local anthropogenic drivers, are 
increasingly impacting forest structure and function (Reyer et al. 2015). As the human population continues to grow, these processes are likely to continue to affect forested ecosystems into the future. Consequently, it is imperative to develop a better understanding of the changing biological processes related to climate and land-use change in forests (Jump et al. 2006; Carnicer et al. 2011; Peng et al. 2011; Reyer et al. 2015).

The dominant responses in forested ecosystems to gradual declines in rainfall, increasing temperatures and climate extremes, such as droughts and heat waves, are crown dieback and/or tree mortality (e.g. Phillips et al. 2009; Allen et al. 2010; Carnicer et al. 2011; Peng et al. 2011; Brouwers et al. 2012; Huang and Anderegg 2012; Matusick et al. 2013; Matusick et al. 2014). These responses, however, are highly species specific, with different species showing different levels of resilience (i.e. ability to recover) to the range of biotic and abiotic stressors involved (e.g. Allen et al. 2010; Matusick et al. 2013). While the effects of changing climate on forested ecosystems are not always clear-cut (Ayres and Lombardero 2000; Dale et al. 2001), it is evident that climate change is increasing the frequency and extent of forest disturbances such as insect outbreaks, wildfires, invasive species and pathogens. Different components of global environmental change are often studied and managed independently, but mounting evidence points toward complex non-additive interaction effects between drivers of native species decline (Didham et al. 2007).

The southwest of Western Australia (SWWA) is a unique ecoregion with a Mediterranean-type climate, and is recognised as a 'biodiversity hotspot' (Klausmeyer and Shaw 2009; Mittermeier et al. 2011). Similar to other Mediterranean-climate ecoregions around the world, threats to the unique biodiversity in this region include declining rainfall, clearing of native vegetation and introduced pests and pathogens (Klausmeyer and Shaw 2009). The SWWA has a persistent trend of declining annual rainfall and increasing temperatures since the mid-1970s (Bates et al. 2008), which are projected to continue into the future (CSIRO and BOM 2007; IPCC 2013). Since human settlement, native vegetation has been cleared from around $70 \%$ of SWWA, mainly for agriculture, and is continuing today primarily for mining and urban settlement (Shepherd et al. 2002). Furthermore, introduced pests and pathogens, such as the soil-borne plant pathogen Phytophthora cinnamomi Rands, have had a devastating effect on the native flora and forest ecosystems in the region (Shearer et al. 2007). All of these factors have increasingly been associated with declines in health of dominant tree species in SWWA (Scott et al. 2009; Brouwers et al. 2012; Barber et al. 2013; Matusick et al. 2013; Brouwers and Coops 2016).

In parallel with the persistent changes in climate since the mid-1970s (Bates et al. 2008), the endemic fungal canker pathogen Quambalaria coyrecup Paap has increasingly caused declines in marri (Corymbia calophylla (Lindl.) K.D. Hill \& L.A.S. Johnson) health in SWWA. Marri, formerly classified as Eucalyptus calophylla, is a bloodwood tree species endemic to SWWA. The first stem cankers of marri were recorded in the outskirts of the capital city Perth in 1939-1940 (MacNish 1963). Further surveys by Cass Smith (1970) located cankered marri trees in additional regions across its range, and in more recent years the canker disease has become severe and widespread, leading to tree decline and death at various locations (Shearer 1992; Shearer 1994; Paap et al. 2008; Paap et al. 2017). Marri has a high conservation value as it provides key products and services for both human and native fauna populations in SWWA. The decline in health of marri will consequently have a negative impact on the provision of these and other services (Shearer 1992). As such, it is important to determine where and to what extent the disease is present within the marri range and whether predisposing and inciting factors can be determined and countered through management action.

In this study, we wanted to answer the following questions: (i) what is the distribution and incidence of marri canker disease across SWWA, and (ii) what are the potential predisposing location-specific factors of canker incidence across the geographical range of marri? For these analyses, we focussed on factors related to climate, climate change, disturbance and presence of Phytophthora spp. known to be pathogenic to marri. The apparent parallel trends of increased canker incidence (Paap et al. 2008; Paap et al. 2017) and the observed climatic changes (Bates et al. 2008), as well as findings from a previous study on wandoo (Eucalyptus wandoo Blakely) in SWWA (Brouwers et al. 2012) informed the selection of these specific factors.

\section{Materials and methods}

\subsection{Study species and area}

The SWWA has a Mediterranean climate characterised by warm to hot, dry summers and mild to cool, wet winters (following Peel et al. 2007). Marri, also known as red gum, is a woodland and forest species with a restricted range across SWWA, between $28^{\circ} 51^{\prime} \mathrm{S}, 114^{\circ} 58^{\prime} \mathrm{E}$ in the north and $34^{\circ} 36^{\prime}$ $\mathrm{S}, 118^{\circ} 44^{\prime} \mathrm{E}$ in the south (Fig. 1). Marri is part of the Myrtaceae family and grows up to $60 \mathrm{~m}$ tall, characterising itself among the bloodwoods by its large fruits and red gum that is often readily visible on the trunk. Marri occurs in areas receiving between 360 and $1150 \mathrm{~mm}$ annual rainfall with average annual temperatures ranging between 14 and $21{ }^{\circ} \mathrm{C}$ (based on averages for 1981-2010: derived from the Australian Water Availability Project (AWAP) dataset, see Jones et al. 2009; Raupach et al. 2009; Raupach et al. 2011). 


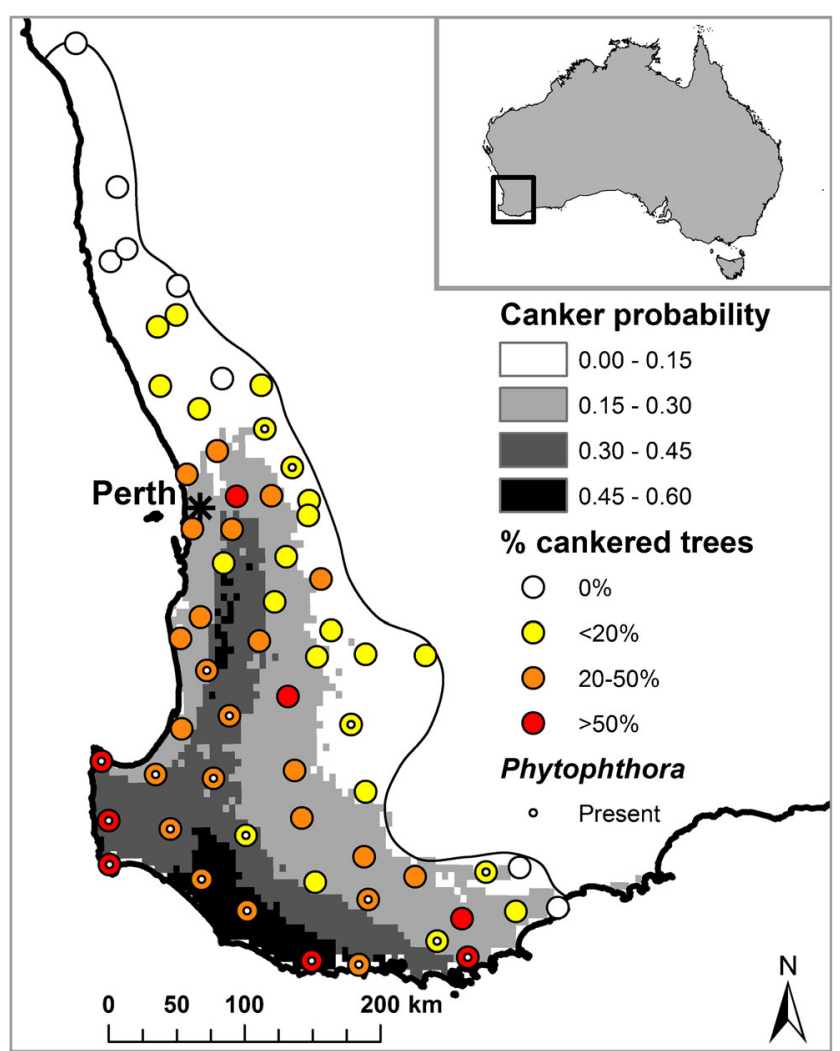

Fig. 1 Location of 62 survey sites across the full range of marri (C. calophylla) in southwest Western Australia. Dots indicate the proportion of canker incidence at each site (trees: $n=50$ ) and if pathogenic Phytophthora spp. were present. The line indicates the inland boundary of the marri range. The different shades of grey across the range are the indicative probability of marri trees being infected by canker disease based on the multivariate (quasibinomial) logistic regression model including average annual rainfall and temperature (i.e. Canker probability $=\operatorname{Exp}(0.8798+(0.002721 \times$ annual average rainfall $1951-1980)+(-0.2627 \times$ annual average temperature 1951-1980) $) /$ $(1+(\operatorname{Exp}(0.8798+(0.002721 \times$ annual average rainfall 1951-1980) + $(-0.2627 \times$ annual average temperature $\left.1951-1980)))) ; R^{2}=0.40\right)$. Map based on 30-year average climate raster files with $5 \times 5 \mathrm{~km}$ pixels

\subsection{Soil/vegetation associations}

Across its range, marri grows in open-forest and woodland formations (Boland et al. 1984). On the northwestern lateritic soils and alluvial clays, marri is usually co-occurring with jarrah (Eucalyptus marginata Sm.) (Churchill 1968), and on the drier eastern side of its northern range, it can be found in association with other eucalypts such as wandoo, powderbark wandoo (Eucalyptus accedens W.Fitzg.) and Western Australian flooded gum (Eucalyptus rudis Endl.) (Boland et al. 1984). Over most of the southern inland range, marri grows on lateritic soils together with jarrah and blackbutt (Eucalyptus patens Benth.), and toward the more southerly extent of its range it is found in association with jarrah and karri (Eucalyptus diversicolor F.Muell.) (Churchill 1968).

\subsection{Field survey and location-specific variables}

A field survey was undertaken between 25 March 2013 and 20 August 2013 to assess the incidence of cankers on marri trees at 62 sites across its entire geographical range (Fig. 1). The Florabase 2.7 dataset (Department of Parks and Wildlife 2013) and maps of the marri range (French 2012) were examined to ascertain the extent of marri in the landscape. To sample the entire marri distribution equally, its range was gridded into $50 \mathrm{~km} \times 50 \mathrm{~km}$ grid cells and a maximum of three sites within each grid cell were selected and assessed. The site selection criteria in each grid cell were as follows: (1) accessibility by public road, and (2) presence of a minimum of 50 marri trees within a 100-m radius circle at each location. The second criterion was based on a pilot study to determine the optimum sample size. Consequently, the majority of sites consisted of stands of marri trees along a road, often adjacent to pasture or arable land, with weeds as understorey. As sites were generally located along road edges, they consisted of a strip of trees within the boundaries of the $100-\mathrm{m}$ radius circle, with the width, length and direction determined by the surrounding land configuration.

At each site, 50 living trees were visually assessed and evaluated for the presence or absence of cankers on the stem and/or branches based on the symptoms and signs associated with $Q$. coyrecup. These include excessive bleeding (gummosis) staining the trunk or limb dark red, splitting and eventual shedding of the bark to reveal perennial cankers, and sporulation of the pathogen visible as powdery white masses within the cankered area (Paap et al. 2008; Paap et al. 2017). The number of standing trees present that had died as a result of clearly visible stem girdling cankers was recorded for each site.

GPS points were taken at the start and end of each survey site with a handheld Garmin Colorado (GARMIN International, Kansas, USA) with an accuracy of $15 \mathrm{~m}$. These GPS points were used to determine the centre point of each of the surveyed sites, and centre points were then used to extract the values of the variables from the relevant digitised datasets using ArcGIS 10 (ESRI, Redlands, CA, USA). For each site, the number of trees with cankers was converted into a proportion by dividing the number of affected trees by the total number of surveyed trees. These proportions were used to investigate the relationships of canker incidence with location-specific variables including climate (i.e. annual averages for rainfall and temperature between 1951-1980 and 1981-2010), climate change (i.e. proportional change in rainfall and temperature since 1980 calculated as the difference between the annual average of 1981-2010 and 1951-1980 divided by the annual average of 1951-1980), disturbance (i.e. proportion of non-native vegetation) and pathogenic Phytophthora spp. presence. 
The climate datasets were derived from the AWAP dataset (Run 26c, 2011, 5 km resolution) (Jones et al. 2009; Raupach et al. 2009; Raupach et al. 2011). To calculate our long-term averages, we used 30 -year periods as this is common practice in climatological research. Scientists agree that the amount of annual precipitation shifted in SWWA during the mid-1970s (Bates et al. 2008); however, there is poor agreement on exactly what year constitutes a good split between climate periods. Similar to Brouwers et al. (2013), we used the year 1980 in order to allow for a complete 30-year average that included the driest year on record in 2010. The period 1951-1980 in this study, therefore, constitutes the climate reference period for SWWA.

The proportion of non-native vegetation (i.e. disturbance) was determined as the area surrounding each survey site that was not identified as 'native vegetation' in the Native Vegetation Extent dataset (Department of Agriculture and Food, Western Australia, 2012, 10 m resolution). This spatial dataset is updated annually, and records all areas that are converted from native vegetation into human land-use, such as roads, arable land and pasture. This proportion of non-native vegetation area can therefore be regarded as a proxy for anthropogenic disturbance, and was computed as the proportion of non-native vegetation within a 100-, 200-, 300-, 400- and $500-\mathrm{m}$ buffer radius around the centre points of each survey site using ArcGIS.

\subsection{Isolation of Phytophthora spp.}

Soil and root samples specifically targeting the root area close to (cankered) marri trees were collected from four locations in each site, and bulked into a single composite sample. Phytophthora spp. presence was established in the laboratory by flooding and baiting soil and root samples according to the method of Aghighi et al. (2012). As lesions developed, the baits were plated onto a modified recipe of NARPH agar, a selective medium for Phytophthora (Huberli et al. 2000) from which pentachloronitrobenzine was excluded. Pure cultures of Phytophthora were then isolated by repeated subculturing. Phytophthora spp. were identified to species level through isolation, amplification and sequencing of DNA, and subsequent phylogenetic analysis according to the methods of Burgess et al. (2009).

\subsection{Statistical analyses}

All analyses were performed using $\mathrm{R}$ version 3.3 .2 ( $\mathrm{R}$ Development Core Team 2009). To investigate the relationships between marri canker incidence and the independent variables (i.e. climate, rainfall and temperature change, proportion of non-native vegetation and Phytophthora presence) plus cross-product terms, logistic regressions for proportion data following Crawley (2007) were performed.
Overdispersion (i.e. high levels of unexplained variability) was detected in all binomial models. To correct for this overdispersion, family = quasibinomial was used for the model significance tests (Crawley 2007).

To account for multicollinearity in the multivariate regressions, first Spearman rank correlation was performed to identify the variables that were correlated. All variables with an $r>0.70$ were put together into groups. Univariate logistic regressions were performed to select one variable from each group based on the $R^{2}$ and level of significance. These selected (uncorrelated) variables and relevant cross-product terms were included in the multivariate regression analysis. Upward selection analysis was performed using binomial models based on the Akaike information criterion for finite sample sizes $\left(\mathrm{AIC}_{\mathrm{c}}\right)$. The topmost models with delta $<5$ were further investigated using family quasibinomial (to correct for overdispersion) and selected based on goodness-of-fit following Logan (2010) and Crawley (2007). The selection criteria included the following: (1) significance of individual variables adding to the model ( $t$ statistic had to be $P<0.05$ ), (2) model goodness-of-fit tests based on model residuals (dispersion), (3) variable goodness-of-fit tests based on residuals (log odds ratio linearity, influence measures Cook's distance) and (4) model comparison based on (adjusted) $R^{2}$ values. For the most parsimonious and best-fit multivariate model, an indicative probability map was created by inputting the logistic regression equation (Eq. 1) and the related model estimates $\left(\beta_{0}\right.$ and $\left.\beta_{\mathrm{i}}\right)$ and variable values $\left(x_{\mathrm{i}}\right)$ of the best model in the Raster calculator tool in ArcGIS.

Logistic regression equation

$y\left(x_{i}\right)=\frac{e^{\beta_{0}+\beta_{i} x_{i}}}{1+e^{\beta_{0}+\beta_{i} x_{i}}}$

\section{Results}

Since 1980, all surveyed sites experienced a reduction in rainfall and increase in temperature. Average rainfall decreases ranged from 2.2 to $136.1 \mathrm{~mm}$ and average temperature increases ranged from 0.17 to $0.53{ }^{\circ} \mathrm{C}$ across all sites. Of the 62 sites surveyed, 8 sites had no cankered trees with the remaining sites showing canker incidence ranging from 2 to $78 \%$ of all surveyed trees (Fig. 1). Thirty-five of the 62 sites included trees that had died following canker development, amounting up to $14 \%$ of the trees that were surveyed at each site.

The variable groups that were uncorrelated with each other $(r<0.70)$ included measures of the following: average rainfall, average temperature, Phytophthora spp. presence, proportion non-native vegetation area, rainfall change, temperature change and cross-product terms. From each of these 
Table 1 Relationships between the independent variables and marri canker incidence across the geographic range of marri (C. calophylla). Only noncorrelated variables and cross-product terms with the highest significance are listed. Proportion non-native vegetation area in a 100-m radius around the survey sites. Model used: Logistic regression for proportion data, family = quasibinomial, following Crawley (2007)

\begin{tabular}{|c|c|c|c|c|c|c|c|}
\hline Explanatory variables $\left(x_{\mathrm{i}}\right)$ & $\beta_{\mathrm{i}}$ & SE & $t$ & $P$ & $\beta_{0}$ & df & $R^{2}$ \\
\hline Average annual rainfall (1951-1980) & 0.0029 & 0.0005 & 5.389 & $<0.001$ & -3.5418 & 60 & 0.34 \\
\hline Average annual temperature (1951-1980) & -0.3071 & 0.1197 & -2.565 & 0.013 & 3.7659 & 60 & 0.10 \\
\hline Phythopthora presence & 0.7388 & 0.2817 & 2.622 & 0.011 & -1.5157 & 60 & 0.10 \\
\hline Proportion non-native vegetation area & 0.9627 & 0.5379 & 1.790 & 0.079 & -1.8736 & 60 & 0.05 \\
\hline Proportional rainfall change & 10.9106 & 6.1145 & 1.784 & 0.079 & -2.0896 & 60 & 0.05 \\
\hline Proportional temperature change & 31.5861 & 25.0724 & 1.260 & 0.213 & -1.8373 & 60 & 0.02 \\
\hline Proportional rainfall change: & 302.1098 & 176.1054 & 1.716 & 0.091 & -1.7101 & 60 & 0.05 \\
\hline
\end{tabular}

groups, univariate logistic regression analyses identified the most significant variables (Table 1) that were all subsequently used in the multivariate regression analyses.

\subsection{Canker incidence and Phytophthora spp.}

Phytophthora spp. were recovered from 34 of the 62 sites, with two to three species recovered from eight sites. The species recovered were as follows: Phytophthora versiformis T. Paap \& T.I. Burgess $(n=17)$, Phytophthora multivora P.M. Scott \& T. Jung $(n=13)$, Phytophthora cinnamomi $(n=8)$, Phytophthora elongata A. Rea, M. Stukely \& T. Jung $(n=4)$ and Phytophthora boodjera A.V. Simamora \& T.I. Burgess $(n=1)$. The pathogenicity of $P$. cinnamomi, $P$. multivora and $P$. elongata to marri seedlings has been demonstrated in glasshouse trials; however, P. boodjera was not pathogenic (L. Croeser, unpublished). P. versiformis, while regularly associated with marri, does not appear to be pathogenic (Paap et al. 2017), and, together with P. boodjera, was excluded from the analysis. Thus, of the 62 sites, 20 sites were found with one or more species of Phytophthora known to be pathogenic to marri. Although there was a significant positive relationship between the presence of pathogenic Phytophthora and the incidence of cankered marri trees at the surveyed sites (Table 1), Phytophthora was not selected in the multivariate models (Table 2). Phytophthora presence was further found to be unrelated to the disturbance proxy we used (i.e. proportion of non-native vegetation).

\subsection{Canker incidence and climate, climate change and disturbance}

From the uncorrelated variables tested, canker incidence was found to be higher in wetter (Fig. 2a) and cooler (Fig. 2b) areas of the marri distribution (Table 2). Average annual rainfall and temperature for the period 1981-2010 (both highly correlated with their 1951-1980 counterparts) were equally found to be related to canker incidence, but showed lower significance and $R^{2}$ values, and were consequently omitted from inclusion in the multivariate logistic regression analyses.

Canker incidence was further found to be significantly related with the proportion of non-native vegetation at a $100-\mathrm{m}$ radius circle surrounding the survey sites (Table 2), indicating higher canker incidence with more disturbed (i.e. non-native vegetation) area surrounding marri stands. As a proxy for the effects of climate change, proportional rainfall change was found to be marginally significantly $(P<0.10)$ related to canker incidence (Table 1), indicating higher incidence with higher levels of rainfall decline. This factor did, however, not significantly add to the multivariate models. Proportional temperature change and the cross-product interaction of the proportion of rainfall loss and temperature increase since 1980

Table 2 Best-fit multivariate logistic regression models

\begin{tabular}{|c|c|c|c|c|c|c|c|c|c|}
\hline No. & Explanatory variables $\left(x_{\mathrm{i}}\right)$ & $\beta_{\mathrm{i}}$ & $\mathrm{SE}$ & $t$ & $P$ & $\beta_{0}$ & df & $R^{2}$ & Adj. $R^{2}$ \\
\hline \multirow[t]{3}{*}{1} & Average annual rainfall (1951-1980) & 0.0025 & 0.0005 & 4.873 & $<0.001$ & 1.5837 & 58 & 0.44 & 0.41 \\
\hline & Average annual temperature (1951-1980) & -0.3363 & 0.1192 & -2.820 & 0.007 & & & & \\
\hline & Proportion non-native vegetation area & 1.0194 & 0.5045 & 2.020 & 0.048 & & & & \\
\hline \multirow[t]{2}{*}{2} & Average annual rainfall (1951-1980) & 0.0027 & 0.0005 & 5.328 & $<0.001$ & 0.8798 & 59 & 0.40 & 0.38 \\
\hline & Average annual temperature (1951-1980) & -0.2627 & 0.1129 & -2.326 & 0.024 & & & & \\
\hline
\end{tabular}



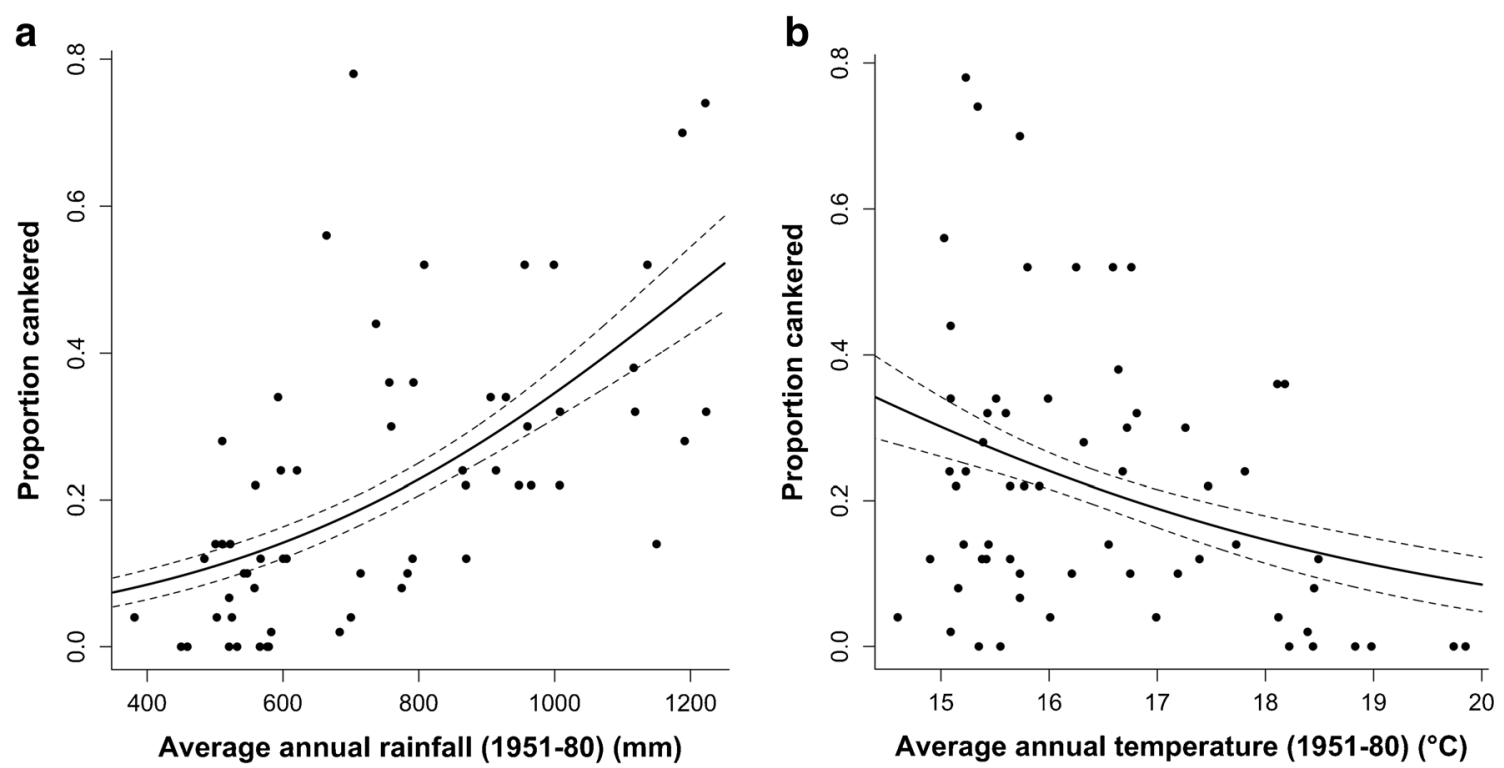

Fig. 2 Relationships between the proportion of cankered marri (C. calophylla) trees and a average annual rainfall (1951-1980), and b average annual temperature (1951-1980). The solid line indicates the predicted probability with 95\% confidence intervals (dotted lines). $n=62$

(Table 1), as well as the other variables tested, were found to be unrelated to canker incidence.

The multivariate models that were identified in the binomial upward selection procedure were all found to be overdispersed, indicating a large portion of unexplained variation in these data. This was equally supported by the relatively low (adjusted) $R^{2}$ values (all < 0.45 ) that were found for the quasibinomial models (Table 2). Based on parsimony (i.e. similar (adjusted) $R^{2}$ values, see Table 2) and a better-fit (i.e. lesser overdispersion of the parameter residuals), the twovariable model, including average annual rainfall (1951-80) and average annual temperature (1951-80), was used to produce an indicative probability map for canker incidence across the marri range, specifically relevant for sites near roads (Fig. $1)$.

\section{Discussion}

Marri canker was found to be widespread across the marri range; however, relatively few trees were affected in the hotter, drier northern limit of its range. The relationships that were found indicate that marri health is likely affected by a combination of factors that are contributing to the incidence of marri canker disease and tree mortality. Our results suggest that anthropogenic disturbance and introduced Phytophthora spp. likely play a role in predisposing marri to the infection by the native fungus $Q$. coyrecup, now resulting in the development of mortality inducing cankers.

The presence of pathogenic Phytophthora was associated with an increased incidence of cankered marri (Table 1). The oomycete genus Phytophthora contains many species that have been implicated in decline and mortality of trees in forest and woodland ecosystems worldwide (Rizzo et al. 2002; Balci and Halmschlager 2003; Dick et al. 2006; Greslebin et al. 2007; Scott et al. 2009). In an investigation of Phytophthora species associated with trees exhibiting crown decline in urban and peri-urban sites of SWWA, Barber et al. (2013) regularly isolated $P$. multivora from marri and raised the possibility that, given their prevalence and impact on root health, Phytophthora may be increasing the susceptibility of marri to canker disease. The role of biotic stressors, such as Phytophthora spp. including P. cinnamomi, P. elongata and $P$. multivora, in predisposing marri to develop cankers is currently under further investigation.

The results from our multivariate models suggest that sitespecific climate characteristics are a significant indicator of canker incidence. Across the marri range, incidence was higher in wetter and cooler areas. Although our measures of climate change did not show a significant effect, the observed changes in climate across the marri range might have contributed to more canker incidence in general. Cooler and wetter conditions are likely beneficial to the pathogen; however, warming and drying climatic conditions may also cause host stress, potentially increasing susceptibility to the pathogen. It is likely that in cooler and wetter areas of the marri range, the pathogenicity of $Q$. coyrecup is not affected by the new treestress-inducing climatic conditions, hence, now causing more severe and mortality inducing cankers.

Even though the epidemiology of marri canker is poorly understood, moisture and temperature are important factors in disease development in any plant community, having direct effects on the pathogen, as well as indirect host effects (Agrios 2005). Marri canker was found more frequently in areas of the 
marri distribution characterised by higher annual rainfall (humidity), especially in the coastal regions. Moisture is indispensable for germination and infection by fungal spores, as well as sporulation, hence dispersal, in many species (Desprez-Loustau et al. 2006). The spread of the fungal pathogen, infection and canker disease development may therefore be naturally suppressed in the drier northern region of the marri range.

While it is accepted that temperature is an important factor governing host-pathogen relationships, interactions between the effects on both the host and pathogen complicate predicting the outcome of increased temperatures (Altizer et al. 2013). Furthermore, literature on the impact of heat stress on pathogens of forest trees is relatively scarce (Desprez-Loustau et al. 2006). Optimum culture growth of Q. coyrecup occurs around $30^{\circ} \mathrm{C}$, with 10 and $35^{\circ} \mathrm{C}$ representing minimum and maximum temperatures for growth (T. Paap, unpublished). While canker was found more frequently in the relatively cooler areas of the marri distribution (i.e. average annual temperature not below $14^{\circ} \mathrm{C}$ ), it is likely that the interaction between temperature and moisture is key. In their explorations of possible effects of climate change on the geographical range or local impact of forest-pathogenic fungi, Desprez-Loustau et al. (2007) found that variables selected for biogeographical models had ecological significance and could usually be explained by the biology of the organism. This supports the assumption that climate is an important determinant of geographic range and spatial variation in activity of these fungi. However, Desprez-Loustau et al. (2007) further highlighted that an important limitation of bioclimatic models stems from the filter effect of host distribution. A set of parameters consistent with the known biology and world distribution of Mycosphaerella pini (Dorog.) M. Morelet, the causal agent of red-band disease of pines, was defined with the CLIMEX simulation model (Sutherst and Maywald 1985), with the resulting map for France suggesting most areas should be climatically suitable for $M$. pini development. However, in the actual distribution, $M$. pini was poorly encountered in the eastern part of the country. In their discussion, Desprez-Loustau et al. (2007) suggested that the absence of $M$. pini in these regions might primarily be explained by the low occurrence of susceptible hosts (Pinus nigra subsp. laricio (Poir.) Maire) more than by climatic constraints. Within the marri range, the population becomes discontinuous in the northern regions. While the climate model supports the absence of disease in this region, it is also plausible that the discontinuous marri occurrence may have limited the ability of the pathogen to reach that area, or that the marri density has not reached a threshold at which a disease outbreak could occur.

Climatic changes have been shown to negatively affect tree species health in SWWA (Brouwers et al. 2012), with drought and heat induced forest dieback and mortality observed in response to extreme climatic conditions (Matusick et al. 2012; Brouwers et al. 2013; Matusick et al. 2013). Since most fungal pathogens require high moisture for dispersal, germination and infection, the direct effects of drought on pathogens are mainly expected to be negative (Jactel et al. 2012). There are a number of reports of negative effects of drought stress on canker diseases. For example, colonisation of young Eucalyptus plants by Chrysoporthe cubensis (Bruner) Gryzenh. \& M.J. Wingf. (previously Cryphonectria cubensis (Bruner) Hodges) was inhibited by drought stress, consistent with observations of the disease being restricted to areas of high rainfall (Swart et al. 1992). Equally, drought stressed 1to 3-year-old honey locust trees had significantly smaller bark cankers than regularly watered trees following artificial inoculation with Thyronectria austro-americana (Speg.) Seeler (Jacobi and Riffle 1989). After conducting a meta-analysis of drought effects on damage by forest pests and pathogens, Jactel et al. (2012) concluded that primary damaging agents (i.e. those that can cause disease on healthy trees) living in woody tissues caused significantly less damage on waterstressed trees, while damage by secondary/opportunistic agents (i.e. those that only exploit trees in poor physiological condition) increased with stress severity. Consequently, drought-induced diseases are often caused by facultative parasites already present on the host as saprophytes (i.e. organisms that live on dead or decomposing matter) or endophytes (i.e. organisms that live in symbiosis within a plant), with water stress triggering host susceptibility and/or breaking pathogen dormancy (Desprez-Loustau et al. 2006). For example, Biscogniauxia mediterranea (De Not.) Kuntze, responsible for 'charcoal disease' necrosis on stems and branches of Quercus species in Mediterranean areas, commonly lives as an endophyte in leaf, twig and bark tissues of healthy vigorous oaks. Its ability to shift from an endophytic to pathogenic phase is mediated by water stress conditions of the host, and under severe water stress $B$. mediterranea develops rapidly within the xylem, potentially killing the entire host (Vannini and Valentini 1994; Desprez-Loustau et al. 2006).

In addition to pathogen functional groups, the intensity and timing of drought are important considerations, as is the hostpathogen interaction, with many pathogens able to grow at water potentials below those that become limiting for growth of their host (Desprez-Loustau et al. 2006). Drought stress is not required for infection of container and field grown marri seedlings by $Q$. coyrecup (T. Paap, unpublished); however, the moisture limits for growth of $Q$. coyrecup have not been determined and are currently being investigated. Whether Q. coyrecup can be present as a latent endophyte on asymptomatic marri is currently unknown, and clarification of this will further inform predictions of how the pathogen may behave under future climate scenarios. Finally, genetic variation in host or pathogen has been reported as sources of variation in the response of trees to drought and infection by fungal 
pathogens (Desprez-Loustau et al. 2006). To this end, large quantitative genetic trials have recently been established for marri to allow assessment of variation in disease susceptibility and drought resistance within the population (T. Paap, unpublished).

Paap et al. (2017) showed that disease incidence was significantly greater in anthropogenically disturbed areas when looking at three regions of the marri range. Results of the current study confirmed that across the entire marri distribution, canker incidence was higher in areas with a greater proportion of non-native vegetation, which is used here as a proxy for disturbance. Trees in urban and peri-urban areas are subjected to a range of stresses including the 'Heat Island Effect'; high levels of air, water and soil pollution; wounds due to repeated pruning; soil compaction and sealing; and frequent root disturbance from utilities operations (Tubby and Webber 2010). Consequently, it is predicted that trees in these environments will experience physiological stresses due to climate change more intensely than forest trees, potentially increasing their susceptibility to endemic pests and pathogens (Tubby and Webber 2010; Pautasso et al. 2015). Similarly, the health and vigour of remnant stands of trees in agricultural landscapes are challenged by agricultural practices (Boutin and Jobin 1998; Hobbs 2001), with links between poor tree health and soil nutrient enrichment (Granger et al. 1994; Davidson et al. 2007; Close et al. 2008) and decreases in the prevalence of beneficial mycorrhizal fungi (Ishaq et al. 2013; Scott et al. 2013). The results for marri suggest that similar processes play a role in the predisposition to canker development. In order to better understand the key drivers of this decline-mechanism, further studies examining the role of anthropogenic disturbance at a finer resolution have been initiated.

\section{Conclusion}

This landscape-scale study has revealed that local biotic and abiotic processes are likely contributing to the incidence of canker development in marri. Very limited research has been undertaken at the stand or community level to study the effects of combined biotic and abiotic stress (Desprez-Loustau et al. 2006); however, following recommendations by Reyer et al. (2015), investigation across multiple spatio-temporal scales of the various factors and their interactions involved in the observed canker epidemic is required to assist sustainable management of marri. In addition, a better knowledge of the importance of genetic diversity and stand heterogeneity in providing resistance against disease outbreaks by this native pathogen is needed. Further research is currently underway to elucidate the role of anthropogenic disturbance on disease incidence. Determining whether $Q$. coyrecup is present as an endophyte on marri will also fill an important gap in the epidemiology of this species. This study has indicated factors and areas of conservation concern and will aid in the targeted conservation efforts for the preservation of marri in the SWWA landscape.

Acknowledgements We thank Sarah Sapsford, Emma Steel and Patsy Stasikowski for comments on the draft manuscript, as well as two anonymous reviewers. We also thank Diane White for sequencing Phytophthora isolates.

\section{Compliance with ethical standards}

Funding This work was supported by the Australian Research Council (Linkage Project 120200581) and conducted within the Western Australian State Centre of Excellence for Climate Change Woodland and Forest Health, which is a partnership between private industry, community groups, universities and the Government of Western Australia.

Conflict of interest The authors declare that they have no conflict of interest.

\section{References}

Aghighi S, Hardy GESJ, Scott JK, Burgess TI (2012) Phytophthora bilorbang sp. nov., a new species associated with the decline of Rubus anglocandicans (European blackberry) in Western Australia. Eur J Plant Pathol 133:841-855. doi:10.1007/s10658012-0006-5

Agrios GN (2005) Plant pathology. Elsevier Academic Press, Burlington, MA

Allen CD, Macalady AK, Chenchouni H, Bachelet D, McDowell N, Vennetier M, Kitzberger T, Rigling A, Breshears DD, Hogg EH, Gonzalez P, Fensham R, Zhang Z, Castro J, Demidova N, Lim JH, Allard G, Running SW, Semerci A, Cobb N (2010) A global overview of drought and heat-induced tree mortality reveals emerging climate change risks for forests. For Ecol Manag 259:660-684

Altizer S, Ostfeld RS, Johnson PTJ, Kutz S, Harvell CD (2013) Climate change and infectious diseases: from evidence to a predictive framework. Science 341:514-519. doi:10.1126/science.1239401

Ayres MP, Lombardero MJ (2000) Assessing the consequences of global change for forest disturbance from herbivores and pathogens. Sci Total Environ 262:263-286. doi:10.1016/S0048-9697(00)00528-3

Balci Y, Halmschlager E (2003) Incidence of Phytophthora species in oak forests in Austria and their possible involvement in oak decline. For Pathol 33:157-174. doi:10.1046/j.1439-0329.2003.00318.x

Barber PA, Paap T, Burgess TI, Dunstan W, Hardy GESJ (2013) A diverse range of Phytophthora species are associated with dying urban trees. Urban For Urban Gree 12:569-575. doi:10.1016/j.ufug.2013. 07.009

Bates B, Hope P, Ryan B, Smith I, Charles S (2008) Key findings from the Indian Ocean Climate Initiative and their impact on policy development in Australia. Clim Chang 89:339-354. doi:10.1007/ s10584-007-9390-9

Boland DJ, Brooker MIH, Chippendale GM, Hall N, Hyland BPM, Johnston RD, Kleinig DA, Turner JD (1984) Forest trees of Australia. Nelson-CSIRO, Melbourne, Australia

Boutin C, Jobin B (1998) Intensity of agricultural practices and effects on adjacent habitats. Ecol Appl 8:544-557. doi:10.2307/2641092

Brouwers NC, Coops NC (2016) Decreasing net primary production in forest and shrub vegetation across southwest Australia. Ecol Indic 66:10-19. doi:10.1016/j.ecolind.2016.01.010 
Brouwers NC, Matusick G, Ruthrof K, Lyons T, Hardy G (2013) Landscape-scale assessment of tree crown dieback following extreme drought and heat in a Mediterranean eucalypt forest ecosystem. Landsc Ecol 28:69-80. doi:10.1007/s10980-012-9815-3

Brouwers NC, Mercer J, Lyons T, Poot P, Veneklaas E, Hardy G (2012) Climate and landscape drivers of tree decline in a Mediterranean ecoregion. Ecol Evol 3:67-79. doi:10.1002/ece3.437

Burgess TI, Webster JL, Ciampini JA, White D, Hardy GES, Stukely MJC (2009) Re-evaluation of Phytophthora species isolated during 30 years of vegetation health surveys in Western Australia using molecular techniques. Plant Dis 93:215-223. doi:10.1094/PDIS93-3-0215

Carnicer J, Coll M, Ninyerola M, Pons X, Sanchez G, Penuelas J (2011) Widespread crown condition decline, food web disruption, and amplified tree mortality with increased climate change-type drought. P Natl Acad Sci USA 108:1474-1478. doi:10.1073/pnas.1010070108

Cass Smith WP (1970) Stem canker disease of red flowering gums. J Dep Agric West Aust 11:33-39

Churchill DM (1968) The distribution and prehistory of Eucalypt diversicolor F. Muell., E. marginata Donn ex Sm., and E. calophylla R. Br. in relation to rainfall. Aust J Bot 16:125-151. doi:10.1071/BT9680125

Close DC, Davidson NJ, Watson T (2008) Health of remnant woodlands in fragments under distinct grazing regimes. Biol Conserv 141: 2395-2402. doi:10.1016/j.biocon.2008.07.006

Crawley MJ (2007) The R book. Wiley, Chichester, England

CSIRO \& BOM (2007) Climate change in Australia - technical report. CSIRO, Australia

Dale VH, Joyce LA, McNulty S, Neilson RP, Ayres MP, Flannigan MD, Hanson PJ, Irland LC, Lugo AE, Peterson CJ, Simberloff D, Swanson FJ, Stocks BJ, Wotton BM (2001) Climate change and forest disturbances. Bioscience 51:723-734. doi:10.1641/00063568(2001)051[0723:ccafd]2.0.co;2

Davidson NJ, Close DC, Battaglia M, Churchill K, Ottenschlaeger M, Watson T, Bruce J (2007) Eucalypt health and agricultural land management within bushland remnants in the midlands of Tasmania, Australia. Biol Conserv 139:439-446. doi:10.1016/j. biocon.2007.07.019

Department of Parks and Wildlife (2013) Western Australian Herbarium (1998-). Florabase 2.7. The Western Australian Flora. Department of Parks and Wildlife. https://florabase.dpaw.wa.gov.au/. Accessed 12 March 2013

Desprez-Loustau M-L, Marçais B, Nageleisen L-M, Piou D, Vannini A (2006) Interactive effects of drought and pathogens in forest trees. Ann For Sci 63:597-612

Desprez-Loustau M-L, Robin C, Reynaud G, Déqué M, Badeau V, Piou D, Husson C, Marçais B (2007) Simulating the effects of a climatechange scenario on the geographical range and activity of forestpathogenic fungi. Can J Plant Pathol 29:101-120. doi:10.1080/ 07060660709507447

Dick MA, Dobbie K, Cooke DEL, Brasier CM (2006) Phytophthora captiosa sp. nov. and P. fallax sp. nov. causing crown dieback of Eucalyptus in New Zealand. Mycol Res 110:393-404. doi:10.1016/ j.mycres.2006.01.008

Didham RK, Tylianakis JM, Gemmell NJ, Rand TA, Ewers RM (2007) Interactive effects of habitat modification and species invasion on native species decline. Trends Ecol Evol 22:489-496. doi:10.1016/j. tree.2007.07.001

French M (2012) Eucalypts of Western Australia's wheatbelt. Malcolm French, Padbury, WA

Granger L, Kasel S, Adams MA (1994) Tree decline in southeastern Australia: nitrate reductase activity and indications of unbalanced nutrition in Eucalyptus ovata (Labill.) and E. camphora (R.T. Baker) communities at Yellingbo, Victoria. Oecologia 98:221-228. doi: $10.1007 / \mathrm{bf} 00341475$
Greslebin AG, Hansen EM, Sutton W (2007) Phytophthora austrocedrae sp. nov., a new species associated with Austrocedrus chilensis mortality in Patagonia (Argentina). Mycol Res 111:308-316. doi:10. 1016/j.mycres.2007.01.008

Hobbs RJ (2001) Synergisms among habitat fragmentation, livestock grazing, and biotic invasions in southwestern Australia. Conserv Biol 15:1522-1528. doi:10.1046/j.1523-1739.2001.01092.x

Huang C-Y, Anderegg WRL (2012) Large drought-induced aboveground live biomass losses in southern Rocky Mountain aspen forests. Glob Chang Biol 18:1016-1027. doi:10.1111/j.1365-2486.2011.02592.x

Huberli D, Tommerup IC, Hardy GESJ (2000) False-negative isolations or absence of lesions may cause misdiagnosis of diseased plants infected with Phytophthora cinnamomi. Australas Plant Pathol 29: 164-169

IPCC (2013) Climate change 2013: the physical science basis. Contribution of Working Group I to the Fifth Assessment Report of the Intergovernmental Panel on Climate Change. IPCC, Cambridge University Press, Cambridge, UK

Ishaq L, Barber PA, Hardy GESJ, Calver M, Dell B (2013) Seedling mycorrhizal type and soil chemistry are related to canopy condition of Eucalyptus gomphocephala. Mycorrhiza 23:359-371. doi:10. 1007/s00572-012-0476-5

Jacobi W, Riffle J (1989) Effects of water stress on Thyronectria canker of honeylocusts. Phytopathology 79:1333-1337

Jactel H, Petit J, Desprez-Loustau M-L, Delzon S, Piou D, Battisti A, Koricheva J (2012) Drought effects on damage by forest insects and pathogens: a meta-analysis. Glob Chang Biol 18:267-276. doi:10. $1111 / j .1365-2486.2011 .02512 . x$

Jones DA, Wang W, Fawcett R (2009) High-quality spatial climate datasets for Australia. Aust Meteorol Ocean 58:233-248

Jump AS, Hunt JM, Penuelas J (2006) Rapid climate change-related growth decline at the southern range edge of Fagus sylvatica. Glob Chang Biol 12:2163-2174

Klausmeyer KR, Shaw MR (2009) Climate change, habitat loss, protected areas and the climate adaptation potential of species in Mediterranean ecosystems worldwide. PLoS One 4:e6392

Logan M (2010) Biostatistical design and analysis using R: a practical guide. Wiley-Blackwell, Chichester, UK

MacNish GC (1963) Diseases recorded on native plants, weeds, field and fibre crops in Western Australia. J Dep Agric West Aust 4:401-408

Matusick G, Ruthrof K, Brouwers N, Dell B, Hardy GJ (2013) Sudden forest canopy collapse corresponding with extreme drought and heat in a Mediterranean-type eucalypt forest in southwestern Australia. Eur J Forest Res 132:497-510. doi:10.1007/s10342-013-0690-5

Matusick G, Ruthrof KX, Brouwers NC, Hardy GSJ (2014) Topography influences the distribution of autumn frost damage on trees in a Mediterranean-type Eucalyptus forest. Trees 28:1449-1462. doi: 10.1007/s00468-014-1048-4

Matusick G, Ruthrof KX, Hardy GESJ (2012) Drought and heat triggers sudden and severe dieback in a dominant Mediterranean-type woodland species. Open J For 2:183-186. doi:10.4236/ojf.2012.24022

Mittermeier RA, Turner WR, Larsen FW, Brooks TM, Gascon C, Zachos FE, Habel JC (2011) Global biodiversity conservation: the critical role of hotspots. In: Zachos FE, Habel JC (eds) Biodiversity hotspots: distribution and protection of conservation priority areas. Springer-Verlag, Berlin, Heidelberg, pp 3-22. doi:10.1007/978-3642-20992-5 1

Paap T, Burgess TI, Calver M, McComb JA, Shearer BL, Hardy GES (2017) A thirteen-year study on the impact of a severe canker disease of Corymbia calophylla, a keystone tree in Mediterranean-type forests. For Pathol 47:e12292. doi:10.1111/efp.12292

Paap T, Burgess TI, McComb JA, Shearer BL, Hardy GESJ (2008) Quambalaria species, including $Q$. coyrecup sp. nov., implicated in canker and shoot blight diseases causing decline of Corymbia species in the southwest of Western Australia. Mycol Res 112:5769. doi:10.1016/j.mycres.2007.10.005 
Paap T, Croeser L, White D, Aghighi S, Barber P, Hardy GES, Burgess TI (2017) Phytophthora versiformis; a new species from Australia related to P. quercina. Australas Plant Pathol 46:369-378. doi:10. 1007/s13313-017-0499-7

Pautasso M, Schlegel M, Holdenrieder O (2015) Forest health in a changing world. Microb Ecol 69:826-842. doi:10.1007/s00248-0140545-8

Peel MC, Finlayson BL, McMahon TA (2007) Updated world map of the Köppen-Geiger climate classification. Hydrol Earth Syst Sci 11: 1633-1644. doi:10.5194/hess-11-1633-2007

Peng C, Ma Z, Lei X, Zhu Q, Chen H, Wang W, Liu S, Li W, Fang X, Zhou $X$ (2011) A drought-induced pervasive increase in tree mortality across Canada's boreal forests. Nat Clim Chang 1:467-471

Phillips OL, Aragão LEOC, Lewis SL, Fisher JB, Lloyd J, LópezGonzález G, Malhi Y, Monteagudo A, Peacock J, Quesada CA, van der Heijden G, Almeida S, Amaral I, Arroyo L, Aymard G, Baker TR, Bánki O, Blanc L, Bonal D, Brando P, Chave J, de Oliveira ÁCA, Cardozo ND, Czimczik CI, Feldpausch TR, Freitas MA, Gloor E, Higuchi N, Jiménez E, Lloyd G, Meir P, Mendoza C, Morel A, Neill DA, Nepstad D, Patiño S, Peñuela MC, Prieto A, Ramírez F, Schwarz M, Silva J, Silveira M, Thomas AS, Steege Ht, Stropp J, Vásquez R, Zelazowski P, Dávila EA, Andelman S, Andrade A, Chao K-J, Erwin T, Di Fiore A, Honorio C. E, Keeling H, Killeen TJ, Laurance WF, Cruz AP, Pitman NCA, Vargas PN, Ramírez-Angulo H, Rudas A, Salamão R, Silva N, Terborgh J, Torres-Lezama A (2009) Drought sensitivity of the Amazon rainforest. Science 323:1344-1347. doi:10.1126/science. 1164033

Development Core Team R (2009) A language and environment for statistical computing. R Foundation for Statistical Computing, Vienna, Austria

Raupach MR, Briggs PR, Haverd V, King EA, Paget M, Trudinger CM (2009) Australian Water Availability Project (AWAP): CSIRO marine and atmospheric research component: Final report for phase 3. Centre for Australian Weather and Climate Research (Bureau of Meteorology and CSIRO), Melbourne, Australia

Raupach MR, Briggs PR, Haverd V, King EA, Paget M, Trudinger CM (2011) CSIRO AWAP Run 26c historical monthly and annual model results for 1900-2009. Centre for Australian Weather and Climate Research (Bureau of Meteorology and CSIRO) http://www.csiro.au/ awap. Accessed 22 June 2011

Reyer CPO, Brouwers N, Rammig A, Brook BW, Epila J, Grant RF, Holmgren M, Langerwisch F, Leuzinger S, Lucht W, Medlyn B, Pfeifer M, Steinkamp J, Vanderwel MC, Verbeeck H, Villela DM
(2015) Forest resilience and tipping points at different spatiotemporal scales: approaches and challenges. J Ecol 103:5-15. doi: $10.1111 / 1365-2745.12337$

Rizzo DM, Garbelotto M, Davidson JM, Slaughter GW, Koike ST (2002) Phytophthora ramorum as the cause of extensive mortality of Quercus spp. and Lithocarpus densiflorus in California. Plant Dis 86:205-214. doi:10.1094/PDIS.2002.86.3.205

Scott PM, Burgess TI, Barber PA, Shearer BL, Stukely MJC, Hardy GESJ, Jung T (2009) Phytophthora multivora sp. nov., a new species recovered from declining Eucalyptus, Banksia, Agonis and other plant species in Western Australia. Persoonia 22:1-13. doi:10. 3767/003158509X415450

Scott PM, Shearer BL, Barber PA, Hardy GESJ (2013) Relationships between the crown health, fine root and ectomycorrhizae density of declining Eucalyptus gomphocephala. Australas Plant Pathol 42:121-131. doi:10.1007/s13313-012-0152-4

Shearer BL (1992) The ecological implications of disease in the southern forest of Western Australia. In: Research on the impact of forest management in South-West Australia. Occasional Paper 2/92. Department of Conservation and Land Management, Como, Western Australia, pp 99-113

Shearer BL (1994) The major plant pathogens occurring in native ecosystems of south-western Australia. J R Soc West Aust 77:113-122

Shearer BL, Crane CE, Barrett S, Cochrane A (2007) Phytophthora cinnamomi invasion, a major threatening process to conservation of flora diversity in the south-west Botanical Province of Western Australia. Aust J Bot 55:225-238. doi:10.1071/BT06019

Shepherd DP, Beeston GR, Hopkins AJM (2002) Native vegetation in Western Australia: extent, type and status. Resource Management Technical Report no. 249, Department of Agriculture, Government of Western Australia,

Sutherst RW, Maywald GF (1985) A computerised system for matching climates in ecology. Agric Ecosyst Environ 13:281-299

Swart W, Conradie E, Wingfield M, Venter W (1992) Effects of water stress on the development of cambial lesions caused by Cryphonectria cubensis on Eucalyptus grandis. Plant Dis 76:744746

Tubby KV, Webber JF (2010) Pests and diseases threatening urban trees under a changing climate. Forestry 83:451-459. doi:10.1093/ forestry/cpq027

Vannini A, Valentini R (1994) Influence of water relations on Quercus cerris-Hypoxylon mediterraneum interaction: a model of droughtinduced susceptibility to a weakness parasite. Tree Physiol 14:129139. doi:10.1093/treephys/14.2.129 